\title{
Firm Entry, Survival, and Exit
}

\section{Dr. Alper Sönmez}

Department of Economics

Selçuk University, Turkey alpersonmez@selcuk.edu.tr

\author{
Doi:10.5901/ajis.2013.v2n9p160
}

\begin{abstract}
This paper presents a brief literature survey on firm entry, survival, and exit. What happens to new firms subsequent to entry? How are they able to survive? What determines entry, exit, and survival? Is there any effect of industry-, firm-, or countryrelated factors on these issues? How does technological development affect survival? Why are new firms' exit rates so high? Why some firms die, while others survive? These are the basic questions that many economists concern? Decisions of the firms on entry and exit from the market are dependent on a variety of market properties such as competition level, demand, barriers to entry, scale economies, and productivity. There may be positive correlation between entry and exit rates. Firm size, firm age, technological capability, and capital-intensity are some of very important factors on exit, entry, or survival of a firm. Empirical and theoretical studies, although their number is small, investigate various aspects of these topics. Especially new firms' entry and exit process, firms' survival conditions, determinants of entry and exit are a few major research topics. This paper presents the findings of studies conducted by researchers in various countries.
\end{abstract}

Keywords: Entry, Exit, Survival, Turkey

\section{Introduction}

This paper presents a brief literature survey on the determinants of firm entry, survival, and exit. While doing this, a literature review model is used, in other words, this paper is constructed by the findings of studies conducted by researchers in different countries.

What happens to new firms after they entry the market? How are they able to survive? What determines the decision of the firms on entry and exit? Is there any effect of size, age, and technological capability of firm on its survival? How does technological development affect survival? Why are new firms' exit rates so high? Why some types of the firms die, while others survive? These questions are the basic concerns of researches.

Firm entry and exit process can be seen as a market selection process, by this way resources are transferring from less efficient firms to efficient ones, and this encourages the firms to develop new technologies and products. In an industry, firms can exit or go bankruptcy due to nature of work, but they can fail more in some time periods than in others, and some types of firm fail much more often than others. For instance, failure rates of the small new firms are much higher, and researches devote a lot of effort to work out why this is. This paper will examine the causes of this.

In this paper, it can be seen that one factor sometimes does produce different results because of some other factors such as firm-, industry-, and country-characteristics. Entry of new firm into markets is seen as an important phenomenon, since this brings new products and processes, and leads to fierce competition in the market. In recent years, a few empirical studies in a number of countries have analyzed several aspects of this phenomenon, and considerable evidence is obtained on the case across markets. The question of what happens to new firms subsequent to entry is quite important, because the impact of entry on market performance depends not only on the number and size of entrants, but also on how long they last, and how much market share they eventually obtain.

This paper will be consisted of four parts. In the first part, the determinants of firm survival will be examined. Then, we examine the determinants of entry and exit. The third part presents brief evidence on Turkish manufacturing. Lastly, we summarize the findings obtained from the empirical literature.

\section{Determinants of Survival}

A number of empirical studies have conducted to analyze the factors that impact the survival probability of firms in the market. At the firm level, the studies conducted independently of each other have found that the firm size and firm age 
are two major factors that affect the firm survival. These studies have showed that the survival probability increases with firm age and size, although at a decreasing rate. In the United States, Dunne et al. (1989) and Audretsch (1991) find a positive relation between firm age and survival. From the study of Cefis and Marsili, the studies find that the market size and growth rates (Mata \& Portugal, 1994), the characteristics of technology (Audretsch, 1995), and the life cycle (Agarwal \& Audretsch, 2001) are the important factors that impact the survival probability at the industry level (Cefis \& Marsili, 2003: 2).

Audretsch have pointed out that (1) average size, (2) industry capital intensity, (3) industry debt structure, (4) the price-cost margin, (5) $R \& D$, (6) growth rate, and (7) entry rate are the major industry-specific factors which impact the survival probability of new-firm (Audretsch, 1995: 4). It is also argued that startup size, age, export-, R\&D- and capitalintensity, human capital, and debt structure are the firm-specific factors that impact such probability (Audretsch et al., 1997: 3). Audretsch et al. (1997) compared the impact of industry- and firm-specific characteristics on the probability of new-firm survival in the United States, Germany, Canada, Portugal, and Italy. They find that these two characteristics play an important role especially subsequent to entry. However, in the mid- and long-term, the industry-specific characteristics have little influence on the survival probability, while firm-specific ones still exert a very important role in firm survival rates (Audretsch et al., 1997: 3, 8).

\subsection{Role of Firm Characteristics on Survival}

Firm size is one of the major firm-related factors that impact the survival probability. A theoretical model for the positive relationship between firm size and survival was provided by Jovanovic (1982). Later empirical studies find that both firm size and age are positively correlated with the survival of entrants (Elston \& Agarwal, 2004: 5). Dunne et al. (1988 \& 1989), Audretsch (1991 \& 1995), Audretsch and Mahmood (1995) in the United States manufacturing, Mata and Portugal (1994) in the Portuguese manufacturing find a positive relationship between start-up size and survival. In other words, larger firms experience higher survival probabilities than smaller firms. In contrast, Audretsch et al. (1999) find no relationship between start-up size and survival in Italian manufacturing, and they state that the characteristics of Italian manufacturing play an important role in this conclusion. In addition, Segarra and Callejon (2002), in their study for Spain, find that survival appears negatively related to initial size. Entrants show differing survival probabilities subsequent to entry depending on their initial size. Smaller entrants present lower survival probabilities (Segarra \& Callejon, 2002: 6).

Santarelli and Vivarelli (2002), in their study on Italian manufacturing, find that hazard rates are high in the early stages of firm's lifecycle, and survival probability tends to be higher for firms whose start up size is larger (Santarelli \& Vivarelli, 2002: 39).

Mata and Portugal (1994) show that size and ownership structure of a firm as well as industry growth and industry turbulence are important determinants of firm survival in Portuguese manufacturing (Mata \& Portugal, 1994: 228). In addition, Audretsch and Mahmood (1995) find that the survival probability of a new firm is shaped not only by the underlying technological conditions and extent of scale economies, but also by firm-related factors such as ownership status and size (Audretsch \& Mahmood, 1995: 102).

Innovation activity of the firms may increase the survival probability of new firms. Cefis and Marsili, in their study on manufacturing firms in Netherlands, show that innovation is important for the survival of firms, especially for the small and young firms. Also, this effect becomes more important as the survival is examined over longer time periods, from two years to three and half years. They show that small and young firms, whose probability to exit from the market is accepted as high, benefit more from the innovation activity for their survival especially in the long term (Cefis \& Marsili, 2003:17).

Financing constraints of the firm have also influenced survival. The impact of these on firm survival has been examined by several studies. Jovanovic and Evans find that liquidity constraints have a very important effect on firm survival in the United States. They show that constrained firms are smaller than unconstrained firms because former ones start with a suboptimal amount of capital. Constrained firms reinvest earnings back into the business since return on capital of such firms is higher than unconstrained firms (Jovanovic \& Evans, 1989: 808).

Close bank-firm relationships may also improve survival probability. Elston and Agarwal show that survival rates are higher for bank-influenced firms in Germany, in other words, bank-based systems are able to better promote the firm survival (Elston \& Agarwal, 2004: 9).

Audretsch argue that the survival probability is also determined by a firm's price cost margin. According to this argument, a firm's ability to increase price or reduce average cost, ceteris paribus, can have a positive effect on firm survival (Görg \& Strobl, 2000: 2). 
A new literature, focusing on the post-entry performance of firms, has emerged in the last few years. In particular, these studies focus on what happens to new firms subsequent to their entry, both in terms of their survival probability and their growth patterns (Audretsch et al., 1999). Bartelsman et al. (2003), in their study for a group of ten OECD countries, find that post-entry performance of the firms differs significantly between Europe and the Unites States (Bartelsman et al., 2003: 2). The accumulation of experience and assets enforce survivors, and increase the survival probability. Pre-entry experience can also influence survival. Peter Thompson, in his work about the US iron and steel shipbuilding industry of the 19th and early 20th centuries, find that pre-entry experience have a large and extremely persistent effect on survival, and this finding is inconsistent with standard explanations for the role of pre-entry experience on firm performance (Thompson, 2005: 1).

Vivek Ghosal discover that greater uncertainty about profits, in conjunction with higher sunk costs, have a quantitatively large negative impact on the survival probability of smaller firms in the Unites States manufacturing industries (Ghosal, 2003: 21).

According to Agarwal and Gort, there are three key attributes of firms that explain variations in the probability of survival. These are learning-by-doing, differences in the quality of initial endowments, and changes in endowments as a result of net investments (Agarwal \& Gort, 2002).

\subsection{Role of Industry Characteristics on Survival}

One of the major industry-related factors that affect the survival is economies of scale of an industry. Audretsch show that the survival probability of a firm is lower in industries where scale economies play an important role. He finds that the existence of substantial scale economies and a high capital-labor ratio reduce the survival probability in the United States (Audretsch, 1991: 445). For Portuguese manufacturing industry, Mata \& Portugal (1994) reach the same result. In a similar study, Audretsch and Mahmood show that scale economies are relatively important for the survival of firms in the United States (Audretsch \& Mahmood, 1995: 101). Audretsch argue that the post-entry performance of firms is also influenced by the degree of scale economies in an industry (Audretsch, 1995).

Research by Segarra and Callejon for Spain manufacturing industry illustrates that survival probability of the new firms in an industry, which characterized by market power, is higher; on the other hand, it is lower in industries, which compete through advertisement, because these industries put more barriers to the survival of new firms (Segarra \& Callejon, 2002: 12). They also show that industry growth, price-cost margin, mobility of firms, and size of entrants' impact positively firm survival, while advertisement and R\&D impact negatively.

The industry growth rate has also a positive effect on new-firm survival. The probability of a firm to survive is higher in an industry with fast growing. This implies that firms may choose to enter at a larger size in fast growing industries, because of the higher chance of success (Görg et al., 2000: 212). Moreover, it is easier for small entrants to grow and survive in a growing industry. Audretsch et al. (1997), in their study for the United States, Germany, Canada, Portugal, and Italy, find that growth rates have a positive effect on new-firm survival (Audretsch et al., 1997: 5-6).

The level of competition and the predictability of demand in an industry also affect the survival probability. Competition is very important for the efficiency and productivity, and it separates winners and losers. Firms, which are inefficient and cannot cope with competition, are rapidly exiting from the market, while survivors are growing and adapting to market. Görg and Strobl, in their study on Irish manufacturing, argue that if the concentration level of an industry is higher, survival probability of a firm decreases. They state that firms in highly concentrated industries are subject to fierce competition, and this reduces the survival probability (Görg \& Strobl; 2000: 9). Audretsch and Mahmood (1995) find a negative and statistically significant effect of market concentration on the survival of new firms in the United States manufacturing industry. On the other hand, Mata and Portugal (1994) find this effect to be insignificant in Portuguese manufacturing industry. Survival may also partly depend on volatility of market demand. The likelihood of unfavorable surprises in a market with volatile demand is greater, and this decreases the survival probability of the firms (Agarwal \& Gort, 2002: 185).

Technological conditions of the industry are seen as the other important determinant of survival. These conditions have been linked to the new firm's survival probability by Audretsch. He shows that the technological regime and market structure play an important role in explaining the variation of firm survival across manufacturing industries in the United States (Audretsch, 1991). Suarez \& Utterback (1995), they have also tested the survival of firms in the United States, show that the survival is substantially affected by the technology evolution. In addition, Christensen et al. (1998) argue that the combination of market and technological strategies is one of the major predictors for firm's survival in the United States. 
Suarez and Utterback show that survival probability is also affected by entry timing and the evolution of technology in the industry. They state that dominant design ${ }^{1}$ has a strong and significant effect on firms' survival in the United States, and its emergence in an industry may also effect firms' survival. They hypotheses that survival probability of the new firms, which enter an industry before the emergence of a dominant design, is higher than for firms entering after it (Suarez \& Utterback, 1995: 419).

Agarwal and Gort argue that survival probability also depends on the development stage of the market in the cycle from birth to maturity, and on individual firm attributes in the United States (Agarwal \& Gort, 1996: 489).

Other important factor is the minimum efficient scale (MES). If average MES level in an industry is high, then the survival probability of new firms that cannot experience sufficient growth to attain MES level is low (Audretsch, 1991). In other words, if new firms do not able to grow and approach the MES level of industry, they are forced to exit from such industry, and this leads to a relatively low survival probability (Audretsch et al., 1999). It seems reasonable to assume that, the higher MES in an industry, the larger will be new start-ups in order to be able to compete effectively in the market. We would, therefore, expect a positive relationship between the size of entrants and the MES (Görg et al., 2000). The larger entrants are more likely to be closer to the MES needed to operate efficiently in a market, therefore, they are less likely to be vulnerable than smaller firms that operate further up the cost curve (Geroski et al., 2003).

Görg and Strobl, in their study for Irish manufacturing industry, argue that multinationals impact positively on firms' survival rate through technology spillovers, and negatively through the crowding out of rivals. They also state that if the local firms manufacture with high fixed costs, then multinationals by increasing output may force these firms to reduce production. This will cause an increase in the average cost of production, and thus it will reduce the local firms' chance of survival in the long-term, ceteris paribus (Görg \& Strobl, 2000: 12; Aitken \& Harrison, 1999).

\section{Entry and Exit}

\subsection{Theoretical Models}

In the literature, the entry and exit process is modeled by a number of theoretical studies based on the creative destruction of Schumpeterian concept. In this model, it is assumed that a firm enters a market with new technology, and competes with incumbents that use conventional technology. If the new innovator firm can cope with the competition, the entrants will be able to replace the incumbents. If not, they will fail to survive and exit from the market (Ahn, 2001: 5). In this process, only successful firms can survive in the market, and resources are transferred from inefficient firms to efficient firms. This turnover of the firms also facilitates the innovation and the adoption of new technologies. According to Cincera and Galgau (2005: 11), these models classified as passive and active learning models, capital vintage models and product life cycle models as follows:

In passive learning models, it is assumed that firms do not know their productivity when they enter the market, and they learn it over time. If they explore that their productivity is too low compared to their rivals, they decide to exit the market (Cincera and Galgau, 2005: 11).

Another model is the active learning models which assume that firms enter the market, and invest to increase their productivity. If they cope with the competition, they survive in the market. If not, they decide to exit the market (Cincera and Galgau, 2005: 12).

In capital vintage models, it assumed that new technology is embodied in vintage capital, and incumbent firms have to bear the costs of upgrading their capital. In this model, new firms entry into the market plays an important role in the adoption of new technologies. On the other hand, in R\&D based models of economic growth, firms conducting successfully innovation and R\&D activities to upgrade their products or create new ones enter the market, and replace firms manufacturing old and low-tech products (Cincera \& Galgau, 2005: 12).

The last model is the life cycle. In the interpretation of Mata et al. (1995) by Ahn (2001), it is stated that high rates of entry and exit are observed in the earlier stages of product life cycle, because new entrants are more aggressive with experimenting new technology during this stage. If a new product is successful, demand grows and a large number of new firms enter the market. After a period of time, the market develops and demand slows down, and economies of scale become more important. In sum, the number of firms increases at first, but then declines sharply, and finally levels off.

${ }^{1}$ A dominant design is defined by Suarez and Utterback (1995: 416) as a specific path along an industry's design hierarchy, which establishes dominance among competing design paths. 
According to this model, it is assumed that it is relatively easy to enter the market in the beginning of the product life cycle, but it is very hard to survive through the next stage where the number of firms declines sharply (Ahn, 2001: 6). Agarwal and Gort (1996) have suggested a similar argument by stating that "the evolutionary stage of the product cycle plays a key role in determining entry, exit and survival rates of firms".

\subsection{Determinants of Firm Entry and Exit}

The theoretical and empirical literature on the factors that influence entry and exit decisions of the firms can be classified into three categories: (i) firm-specific, (ii) industry-specific, and (iii) country-specific. Table 1 below summarizes these factors that play a major role in entry and exit according to these categories (Cincera \& Galgau, 2005: 20).

Table 1: Determinants of Firm Entry and Exit

\begin{tabular}{|c|c|c|}
\hline Firm Specific Determinants & Industry Specific Determinants & Country Specific Determinants \\
\hline $\begin{array}{l}\text { type of entrant, size, age, } \\
\text { firm growth rate, limit price, } \\
\text { excess capacity, } \\
\text { financial structure, } \\
\text { manager turnover in small firms, } \\
\text { limit price, predatory pricing }\end{array}$ & $\begin{array}{l}\text { lagged entry, lagged exit, } \\
\text { minimum efficient scale of production, } \\
\text { capital intensity, } \\
\text { resource intensity, } \\
\text { maturity degree of the industry, } \\
\text { concentration, differentiation }\end{array}$ & $\begin{array}{l}\text { degree of economic development, } \\
\text { macroeconomic shocks, } \\
\text { access to start-up capital }\end{array}$ \\
\hline
\end{tabular}

Source: Extracted from Cincera and Galgau (2005: 20)

According to neoclassical approach entry and exit are dependent on a variety of market properties such as growth in demand, barriers to entry, and scale economies (Agarwal \& Gort, 1996: 489).

Cincera and Galgau (2005), in their study on entry and exit for European Countries, argue that an increase in the level of deregulation leads to an increase in both entry and exit rate. They state that barriers to both entry and exit impact the possibility of least efficient firms to exit from the market, while they impact the possibility of efficient firms to enter the market (Cincera \& Galgau, 2005: 8-10). Harrigan (1980) also argues that entry barriers discourage the entry decision of firms into the market. If entry barriers are high in an industry, firms can earn high profits because of higher prices exceed costs and no new entry into the market. On the other hand, exit barriers block the firms whose productivity are lower to exit from the market (Harrigan, 1980: 166). If entry and exit barriers in an industry are very minor, then this process moves the market share from inefficient firms to efficient ones. Cincera and Galgau also state that public intervention by implementing various market reforms is one of the major factors that impact the entry and exit decision of firms (Cincera \& Galgau, 2005: 8-10).

Geroski et al. (2003) for Portuguese manufacturing industry find that firm size, human capital, market concentration and growth rate negatively impact exit rate, although their effect is not permanent. On the other hand, they show that entry rate is highly positively correlated with exit rate. They argue that founding conditions of the firms play an important role in the exit rates, and in some cases they can be more crucial than current conditions. They also state that these conditions have long lasting impact on the survival probability although their effects decrease with time, and reversal of the initial decisions to improve the survival cannot be possible after the foundation of the firm (Geroski et al., 2003: 2).

Sunk costs can also impact on both exit and entry decision of the firms. The studies by Audretsch (1991 \& 1995) and Audretsch et al. (1999) show that a greater degree of sunk costs should reduce the probability of exit, and lead to lower growth rates of surviving firms.

The characteristics of the industry and inter-industry differences are the other factors which affect entry and exit decision of the firms. Industries that require a high amount of sunk capital present lower rates of entry and exit. For instance, industries based on economies of scale and on natural resources experience the lowest entry and exit rates, because sunk costs are very high in these industries. On the other hand, labor intensive and product differentiated industries, which require relatively lower set-up costs, give rise to high exit and entry rates because of fierce competition in these industries. In addition, innovative and R\&D based industries are more risky; firms that enter these industries face high exit rates. (Segarra \& Callejon, 2002: 8). 
General economic condition is also a factor that affects the decisions of firms in terms of enter and exit the market. A favorable economic condition negatively affects exit decisions of firms from a market (Kranenburg et al., 2002: 285).

According to another argument by Segarra and Callejon, entrants cannot be sure about their own relative efficiency, and they enter the market with small investment commitment with the objective of "trying" or "looking" into the market, and "learning" about their possibilities in time. If they explore that their capabilities are not enough to cope with the competition, they will exit subsequent to entry (Segarra \& Callejon, 2002: 2).

Mata and Portugal (1994) point out that larger entrants and firms that have entered market with multiple establishments are more likely to stay in the market for more periods. Exit of multiplant firms is less likely since it implies the simultaneous failure of all their plants. And, they also pointed out that in growing fast industries, the expected survival rates of new firms is likely to be greater and that can accommodate more new firms, and those in which fewer firms attempt to enter (Mata \& Portugal, 1994: 242).

According to Schary (1991) a firm may leave an industry through merger, voluntary liquidation, or bankruptcy. Different forms of these exits have different economic consequences. In a merger situation, much of the productive capacity may remain in the industry and investors may receive a premium for their shares. In voluntary liquidation, capacity is often removed from the industry and creditors are paid in full, while bankruptcy often leads to permanent close of production capacity and to partial payments to creditors (Schary, 1991: 339).

According to Ghosal (2003), one other determinant of exit and entry is the initial capital and the financial structure of the firm. He proposes that the firms that encounter financial constraints have lower survival probability, and higher exits. Generally, smaller and younger firms face financial difficulties, and they borrow more and have higher probability of failing to pay this borrow. He also showed that the default probability decreases with increasing firm size and age (Ghosal, 2003: 5).

If we look at the relation between entry and exit rates in the literature, it is seen a positive correlation between such rates. This correlation is explained by two arguments. Firstly, the entrants increase the number of firms in the market, and this lead to fierce competition, and thus it facilitates the exits in the market. According to Ahn (2001), turnover rates are higher in innovative industries, and industries with higher entry rates also tend to have higher hazard rates ${ }^{2}$ (Ahn, 2001). Findings of the various studies report that if a firm easily enters the market then the exit of firm from the market is also more likely. Dunne et al. (1988) show that industries with higher entry rates tend to have higher exit rates (Dunne et al., 1988: 496). They also find a very strong positive correlation between the flows of entry and exit across industries in the United States manufacturing. Secondly, if new entrants have lower survival rates than incumbent firms in the market, high entry rate should be associated with high exit (Agarwal \& Gort, 1996: 491).

An interesting argument is done by Ghemawat and Nalebuff in 1985. According to this argument, the exit decision is more closely related to recent models of patent races, continuing to produce is like continuing to do research; exit is comparable to abandoning research (Ghemawat \& Nalebuff, 1985: 185).

\section{Evidence on Turkish Manufacturing}

Kaya and Üçdoğruk (2002), in their empirical study on the entry and exit dynamics of Turkish manufacturing industry for the period 1981-1997, find that profit margin positively affects entry rate, capital intensity represents an entry barrier, there is a positive relationship between growth and entry, the concentration ratio is an important determinant of both entry and exit decision of the firms, an increase in the real wage rate affects negatively entry rates, and the level of labor productivity discourages new firms from entering the market (Kaya \& Üçdoğruk, 2002: 25).

In another study conducted on Turkish manufacturing industry for the period 1983-1996, Özler and Taymaz (2004) analyze the impact of foreign ownership status of the firms on firm survival and growth. They find that entry characteristics of foreign and local firms are different, and their entry level differences persist after entry. Also, foreign firms are more likely survive; foreign ownership and foreign presence do not have any impact on the survival of local firms. Firm characteristics such as size, growth rate of the firm, cost of external funding, profitability, and quality of the labor force are important factors for foreign and local firm survival (Özler \& Taymaz, 2004: 21).

Sak and Taymaz (2004), in their study on Turkish manufacturing industry, find a high difference between small and large firms in the case of entry, exit and growth processes. Enter and exit rates of the small firms are much higher than larger firms. On the other hand, small firms that can survive achieve very high growth rates (Sak \& Taymaz, 2004: 12).

\footnotetext{
2 "The hazard rate is the share of exiting firms in a given year as a percentage of the total number of survivors as of the previous year".
} 


\section{Summary}

The main conclusions drawn from the empirical literature can be summarized as follows:

- A substantial number of firms enter and exit from each industry each year in most countries.

- There are significant differences in survival probability according to the size of the new firms.

- Smaller firms dominate the exit and entry processes within the industry.

- Exiting firms are generally small and young.

- Entrants are small compared to incumbents, and they have high failure rates. Small entrants have a low survival probability on average unless they grow rapidly to a reasonable size. Small firms have higher rates of post-entry growth. Larger firms are older, and they have higher survival rates.

- The entry flows of the firms are accompanied by contemporary exit movements.

- Entry rates change over time, and it reaches to peak in the beginning of the product life cycle of industry.

- Firm turnover rates are higher under more innovative and more competitive environments.

- Entry and exit are intimately involved in the growth-size relation.

- Only a small number of firms can succeed to survive, and acquire market share.

- The industry growth rate impacts positively the survival probability.

- Survival rates present higher variation than entry rates across industries.

- Growth and hazard rates decline with firm age.

- Firm size and firm age are consistently important in explaining survival and growth of entrants.

- Older firms showed lower failure rates and lower growth rates in most studies.

\section{References}

Agarwal, R., \& Gort, M. (1996). The Evolution of Markets and Entry, Exit and Survival of Firms. The Review of Economics and Statistics, 78 (3), 489-498.

Agarwal, R., \& Audretsch, D. B. (2001). Does Entry Size Matter? The Impact of the Life Cycle and Technology on Firm Survival. The Journal of Industrial Economics, 49 (1), 21-43.

Agarwal, R., \& Gort, M. (2002). Firm and Product Life Cycles and Firm Survival. The American Economic Review, 92 (2), 184-190.

Ahn, S. (2001). Firm Dynamics and Productivity Growth: A Review of Micro Evidence from OECD Countries. OECD Economics Department Working Papers, NO. 297, ECO/WKP: 23, 1-66.

Aitken, B. J., \& Harrison, A. E. (1999). Do Domestic Firms Benefit from Direct Foreign Investment? Evidence from Venezuela. American Economic Review, 89 (3), 605-618.

Audretsch, D. B. (1991). New-Firm Survival and the Technological Regime. The Review of Economics and Statistics, 73 (3), $441-450$.

Audretsch, D. B. (1995). Innovation, Growth and Survival. International Journal of Industrial Organization, 13 (4), 441-457.

Audretsch, D. B., \& Mahmood, T. (1995). New Firm Survival: New Results Using a Hazard Function. The Review of Economics and Statistics, 77 (1), 97-103.

Audretsch, D. B., Houweling, P., \& Thurik, A. R. (1997). New-Firm Survival: Industry versus Firm Effects. Tinbergen Institute Discussion Papers, Tinbergen Institute, No. 97-063/3.

Audretsch, D. B., Santarelli, E., \& Vivarelli, M. (1999). Start-Up Size and Industrial Dynamics: Some Evidence from Italian Manufacturing. International Journal of Industrial Organization, 17, 965-983.

Bartelsman, E., Scarpetta, S., \& Schivardi, F. (2003). Comparative Analysis of Firm Demographics and Survival: Micro-Level Evidence for The OECD Countries. OECD Economics Departments Working Papers, No. 348.

Cefis, E., \& Marsili, O. (2003). Survivor: The Role of Innovation in Firms' Survival. Tjalling C. Koopmans Research Institute, Utrecht School of Economics, Discussion Paper Series, 03-18.

Christensen, C. M., Suarez, F. F., \& Utterback, J. M. (1998). Strategies for Survival in Fast-Changing Industries. Management Science, 44, 207-220.

Cincera, M., \& Galgau, O. (2005). Impact of Market Entry and Exit on EU Productivity and Growth Performance. European Commission, Directorate-General for Economic and Financial Affairs, Economic Papers, No. 222.

Dunne, T., Roberts, M. J., \& Samuelson, L. (1988). Patterns of Firm Entry and Exit in U.S. Manufacturing Industries. The RAND Journal of Economics, (19) 4, 495-515.

Dunne, T., Roberts, M. J., \& Samuelson, L. (1989). The Growth and Failure of U.S. Manufacturing Plants. Quarterly Journal of Economics, 104, 671-698.

Elston, J. A., \& Agarwal, R. (2004). Bank Influence, Firm Performance and Survival: Empirical Evidence from Germany 1970-1986. Corporate Ownership and Control, 1 (2), 65-71.

Geroski, P. A., Mata, J., \& Portugal, P. (2003). Founding Conditions and the Survival of New Firms. Banco De Portugal, Economic Research Department, WP 1-03. 
Ghemawat, P., \& Nalebuff, B. (1985). EXIT. The RAND Journal of Economics, 16 (2), 184-194.

Ghosal, V. (2003). Impact of Uncertainty and Sunk Costs on Firm Survival and Industry Dynamics. CIC Working Papers, SP II 2003-12, Wissenschaftszentrum Berlin (WZB), Research Unit: Competitiveness and Industrial Change (CIC), 1-35.

Görg, H., \& Strobl, E. (2000). Multinational Companies, Technology Spillovers and Firm Survival: Evidence from Irish Manufacturing. Centre for Research on Globalisation and Labour Markets, School of Economics, Research Paper, University of Nottingham, 122.

Görg, H., Strolb, E., \& Ruane, F. (2000). Determinants of Firm Start-Up Size: An Application of Quantile Regression for Ireland. Small Business Economics, 4, 211-222.

Harrigan, K. R. (1980). The Effect of Exit Barriers Upon Strategic Flexibility. Strategic Management Journal, 1 (2), 165-176.

Jovanovic, B. (1982). Selection and Evolution of Industry. Econometrica, 50, 649-670.

Jovanovic, B., \& Evans, D. S. (1989). An Estimated Model of Entrepreneurial Choice under Liquidity Constraints. Journal of Political Economy. 97 (41), 808-827.

Kaya, S., \& Üçdoğruk, Y. (2002). The Dynamics of Entry and Exit in Turkish Manufacturing Industry. METU ERC Working Papers in Economics 02/02.

Kranenburg, V. H. L., Palm, F. C., \& Pfann, G. A. (2002). Exit and Survival in a Concentrating Industry: The Case of Daily Newspapers in the Netherlands. Review of Industrial Organization, 21, 283-303.

Mata, J., \& Portugal, P. (1994). Life Duration of New Firms. The Journal of Industrial Economics, 42 (3), 227-245.

Mata, J., Portugal, P., \& Guiimaraes, P. (1995). The Survival of New Plants: Start-Up Conditions and Post-Entry Evolution. International Journal of Industrial Organization, 13, 459-481.

Özler, Ş., \& Taymaz, E. (2004). Does Foreign Ownership Matter for Survival and Growth. METU ERC Working Paper in Economic $04 / 06$.

Sak, G., \& Taymaz, E. (2004). How Flexible are Small Firms? An Analysis on the Determinants of Flexibility. Paper prepared for the ERF Eleventh Annual Conference 14-16 December 2004, Beirut, Lebanon, and Version 5.

Santarelli, E., \& Vivarelli, M. (2002). Is Subsidizing entry an optimal policy?. Industrial and Corporate Change, 11 (1), 39-52.

Schary, M. A. (1991). The Probability of Exit. The RAND Journal of Economics, 22 (3), 339-353.

Segarra, A., \& Callejon, M. (2002). New Firms' Survival and Market Turbulence: New Evidence from Spain. Review of Industrial Organization, 20, 1-14.

Suarez, F. F., \& Utterback, J. M. (1995). Dominant Designs and the Survival of Firms. Strategic Management Journal, 16 (6), 415-430.

Thompson, P. (2005). Selection and Firm Survival: Evidence from the Shipbuilding Industry 1825-1914. The Review of Economics and Statistics, 87(1), 26-36. 